\title{
STUDIES ON MICROBIAL MECHANISMS OF PERMAFROST CARBON CONVERSION TO CLIMATE WARMING: RETROSPECT AND PROSPECT
}

\author{
YU, S. P. - XU, N. ${ }^{*}$ - DING, J. N. - SHI, C. Q. \\ Key Laboratory of Heilongjiang Province for Cold-Regions Wetlands Ecology and Environment \\ Research, and School of Geography and Tourism, Harbin University, Harbin 150086, China \\ ${ }^{*}$ Corresponding author \\ e-mail:xunan0451@126.com \\ (Received 24 $4^{\text {th }}$ Jul 2021; accepted $28^{\text {th }}$ Oct 2021)
}

\begin{abstract}
Recently, very active studies have been undertaken on the response and stability of permafrost carbon pool and key biogeochemical processes in permafrost regions to climate warming. By observing the significant differences in microbial community structure in regions of seasonal frost and permafrost, it is evident that microbes play key roles in the conversion of permafrost carbon. This paper reviews research progress at the cutting edges on the conversion and decomposition of permafrost carbon to climate warming and subsequent changes in microbial activities over the past decade. Findings indicated that: (1) Freezethaw cycles of soils in the active layer in permafrost regions showed an increasing annual trend and the existing survival patterns of permafrost microbes may be altered by the increasing freeze-thaw frequency; and (2) Soil microbes are an essential part of the cold-regions ecosystem and they play vital roles in soil carbon and nitrogen cycling, the mineralization and decomposition of soil organic matter. Thus, climate warming and subsequent permafrost degradation affect the conversion and decomposition of permafrost carbon, resulting in changes in $\mathrm{CO}_{2}$ and $\mathrm{CH}_{4}$ emissions, soil environmental factors, and soil microbial community structures. The laws for governing permafrost carbon conversion and the self-regulation mechanisms of soil microbes are important for natural ecosystems and environments in cold regions, and affect the strengths of greenhouse gas sources and sinks in permafrost regions.
\end{abstract}

Keywords: frozen soils, degenerate, microorganisms, climate change, carbon cycle

\section{Introduction}

Frozen soil generally refers to all kinds of rocks and soils with a temperature of $0^{\circ} \mathrm{C}$ or below and is mainly found in high-latitude or high-altitude regions (Brown et al., 2002). Depending on its geographical distribution, pedogenesis, and diagnostic characteristics, frozen soil can be classified into tundra and frozen desert soil. Considering its geological history and impacts from climate change, permafrost is a geological entity formed through surface-atmosphere material and energy exchanges under the combined effect of geological structures, lithology, regional geographical environments, and other factors. It is also an essential component of the earth's cryosphere (Feng et al., 2004; Schmitt et al., 2008; Lawrence et al., 2015), covering about $24 \%$ of the exposed surface areas of the Northern Hemisphere. With its extensive distribution and unique hydrothermal properties, permafrost has become a very important environmental factor in regulating land surface processes (Bracho et al., 2016).

The occurrence conditions of permafrost are very fragile. Due to the strong influence of human activities such as climate warming and forest logging over the past century, most of the permafrost has begun to degrade, mainly manifested in the continuous northward movement of the south boundary of the permafrost, the gradual regression from south to north, the continuous reduction of the total area, the thinning of the thickness of the permafrost, the thickening of the active layer, the increase of the 
maximum seasonal melting depth The trend of melting and shrinking also intensifies. The original permafrost becomes seasonal permafrost, the continuous permafrost becomes discontinuous, and the multi-year Island permafrost disappears. It is estimated that the global permafrost area will decrease significantly in the next century (Camill and Clark, 2000). With the continuous warming of the climate, the area and speed of permafrost degradation may further increase in the next century. Subsequently, it will cause a series of ecological and hydrological changes, which will lead to changes in vegetation succession and productivity, and may also bring severe ecological and environmental problems in cold areas, that is, the common degradation of frozen soil, wetland and forest (Camill, 1999; Camill and Clark, 2000).

Climate warming has known effects on high-latitude permafrost zones (Natali et al., 2012; Song et al., 2014). According to the latest assessment, the global mean annual ground surface temperature rose by roughly $0.85^{\circ} \mathrm{C}$ from $1880-2012$ (IPCC, 2013). In the past century, the mean annual air temperature of the northern high-latitude region increased by more than $1{ }^{\circ} \mathrm{C}$, changing climatic, hydrological, and mass cycles in permafrost zones (Anisimov and Nelson, 1996; Feng et al., 2020). Permafrost degradation causes the decomposition of the soil organic carbon (SOC) stored in permafrost zones, accounting for $50 \%$ of the global SOC, which in turn feeds back and accelerates climate warming (Luo et al., 2007; Haeberli and Hohmann, 2008; Bracho et al., 2016; Guo et al., 2018; Feng et al., 2020). Studies have shown that very short-term climate warming of only 1.5 years can stimulate rapid decomposition of SOC in permafrost zones (as mediated by microbes), but does not affect soil microbial communities. However, experimental winter warming for a five-year period in the same place showed altered microbial communities (Zhou and Yang, 2020). There are intense interactions between thawing depth, community aggregation and interaction networks, which means that the climate-warming-induced acceleration of permafrost thawing has fundamentally reconstructed microbial communities (Huntington, 2006; Schmitt et al., 2008; Deane-Coe et al., 2015; Guo et al., 2018).

Under a warming climate, there is an increase in both the decomposition of carbon and the relative abundance of methanogenic genes, and their functional structures are closely related to ecosystem respiration or methane emission. This suggests that carbon cyclingrelated microbial responses may have produced positive feedbacks, thus accelerating the decomposition of SOC in permafrost zones. However, in most cases, the loss of SOC incurred by changes in the composition of microbial communities is unlikely to subside. This result is of great significance for the conversion of permafrost carbon and the interactive mechanisms of soil microbes (Jin et al., 2000; Friedlingstein et al., 2006; Shannon et al., 2010; Song et al., 2013). Microbes play a vital role in the biogeochemical cycling in permafrost regions, and can serve as early warning and sensitive bio-indicators of ecosystem changes in cold regions (Song et al., 2004; Bracho et al., 2016; Guo et al., 2018). In the context of global warming, the degradation of permafrost is bound to directly or indirectly affect soil microbial community structures and microbe-regulated soil ecological processes, further changing the structures and functions of permafrost ecosystems.

Based on the Science Citation Expanded (SCIE) database of the Web of Science platform, a quantitative analysis was carried out on the literature of SCI in the field of soil animals from 2010 to 2020, most geocryological studies have focused on soil microbial and environmental changes, a total of 883 relevant literatures (Fig. 1). As temperatures continuously rise, the active layer deepens. In this case, the large amount of SOC 
sequestered in permafrost may be released. On the other hand, as metabolic activity of the soil microbes is enhanced, the decomposition efficiency of organic carbon increases, resulting in large effluxes of greenhouse gases, such as $\mathrm{CO}_{2}, \mathrm{CH}_{4}$, and $\mathrm{N}_{2} \mathrm{O}$. This further enhances the positive feedback of permafrost degradation to climate warming, impacting all ecosystems in cold regions (Jin et al., 2007; Feng et al., 2007; Zhu et al., 2016). Thus, investigating permafrost microbes is scientifically relevant for further understanding of the degradation of biodiversity and permafrost ecosystems. In addition, studying the changes in soil microbial community structures and response mechanisms between them and various soil environmental factors in permafrost zones will further our ability to comprehensively and accurately predict and assess the impacts of future climate change on the functions and stability of permafrost ecosystems.

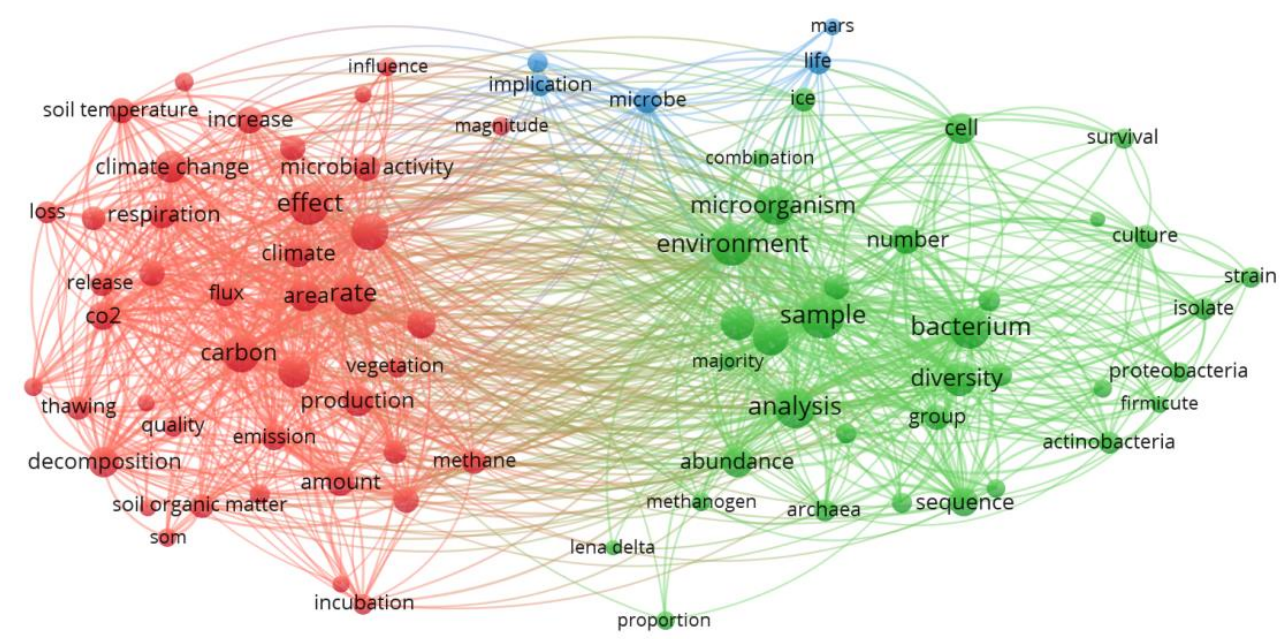

Figure 1. Hotspot distribution of the geocryology research field. Notes: Each circle represents a technical term. The distribution of these terms is based on their occurrence frequency in titles and abstracts. Two terms co-occurring at a higher frequency are closer in the diagram. Each color represents a theme, and the size of a circle is directly proportional to the number of corresponding studies

As one of the extreme environments in the cryosphere, frozen soil covers a large area and is widely distributed. It is sensitive to global climate change. Compared with the traditional terrestrial and aquatic ecosystems of forests, farmland, oceans, lakes, rivers and atmosphere, there are few studies on soil microbial communities in the frozen soil extreme environment that is sparsely populated and not polluted by modern industry (Simth et al., 1998; Dobbie and Simth, 2003). Permafrost distribution area is a sensitive area of global climate change. Permafrost degradation leads to the shrinkage of permafrost area, the decline of soil biodiversity function and the damage of ecological function, which has become one of the important ecological problems at present. The study of frozen soil microorganisms has become a hot field of international research. Over the years, the research on frozen soil in China has made great progress and has been in the leading position in the world. However, the research on frozen soil microorganisms has just started (Puser et al., 2006).

Due to the huge soil carbon storage in the multi-year frozen soil area and its vulnerability to climate warming, microorganisms are considered to be the key to regulate the effect of climate warming on soil carbon. Therefore, the microbial decomposition 
function of soil carbon is enhanced under the condition of global warming, which leads to the increase of soil respiration and methane emission, which in turn accelerates the loss of carbon in the tundra. since the soil temperature during the growing season remains unchanged, these observations may be caused by changes caused by winter warming treatment. For many years, it has been believed that thawing of frozen soil area has a profound influence on local hydrology, heat and dynamics. And found that warming increases the depth of thawing, which is associated with fine the most important factors associated with bacterial phylogeny, community composition, and network topology.

\section{Effects of a warming climate on the conversion of permafrost carbon}

Due to the effects of rising temperature on carbon cycling processes in terrestrial ecosystems (Ping et al., 2015), warming will exert a tremendous influence on global carbon cycling (Xu et al., 2007; Schaefer et al., 2014; Turetsky et al., 2020). Climate warming can affect terrestrial carbon cycling processes through the following mechanisms: affecting surface plant growth and community structures through changing the duration of phenological and growth periods (Walther et al., 2002; Nemani, 2003); influencing soil respiration and nutrient cycling through modifying the activity of soil microbial and the decomposition rate of SOC (Grogan et al., 2000; Johnson et al., 2000; Melillo et al., 2002; Singh et al., 2010) and ultimately impacting the growth and pattern of surface vegetation (Rustad et al., 2001; Walther et al., 2002; Welker et al., 2004); The carbon balance of the terrestrial ecosystem is mainly determined by two processes: photosynthesis and respiration of surface vegetation and soil (Nakatsubo et al., 2005; Grosse et al., 2016). The modification of the carbon cycling processes of the terrestrial ecosystem by warming will promote the above mentioned processes and change the initial carbon balance, creating a positive feedback to the warming process (Grosse et al., 2016). Such feed backs may accelerate the process of climate warming (Natali et al., 2015). Soil is also the largest carbon pool in the terrestrial ecosystem (Post et al., 1982; Wan et al., 2002), and any minor change to the soil carbon pool due to warming may end up a significant impact on the carbon balance of the terrestrial ecosystem. Climate warming accelerates the decomposition of SOC (Hayes et al., 2014) and soil respiration (Natali et al., 2015) (Fig. 2).

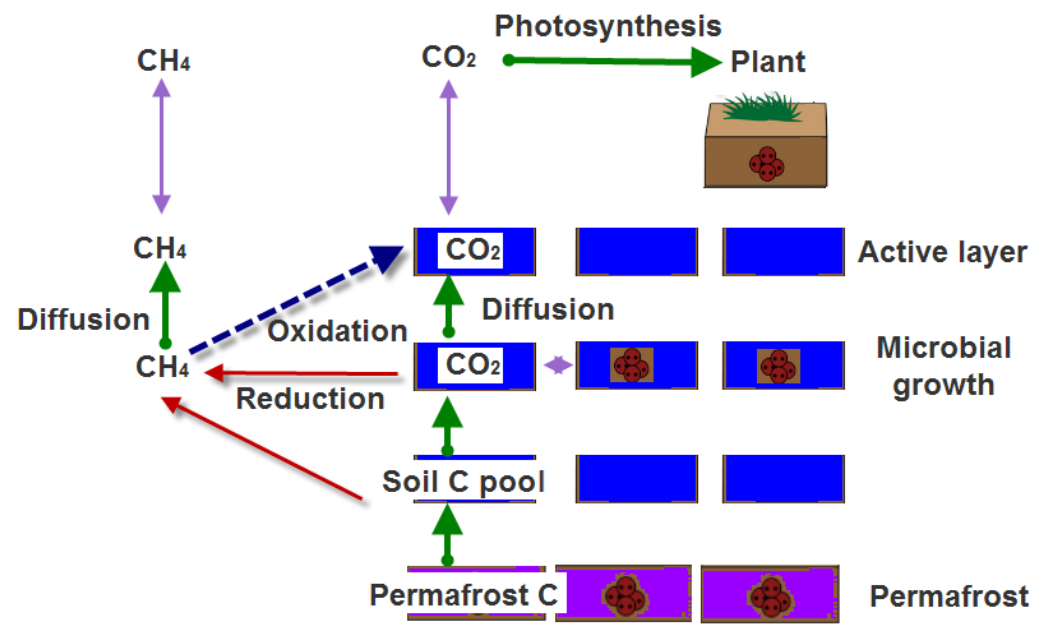

Figure 2. Mechanism of carbon exchange between microbial community and soil 
Existing earth system models mainly focus on how a warming climate affects the thickness and hydrological status of the active layer above the permafrost. Driven by warming, the thickness of the active layer in permafrost region sathigh-latitudes gradually increases. However, in regions with excess ground ice, ground surface settlement occurs during the degradation of permafrost, resulting in thermokarsting and modified hydrology (Merritt et al., 2020). The thickness of active layer in permafrost region is significantly correlated with soil temperature and moisture, thus affecting the carbon emission process of ecosystem (Fig. 3). When thawed soil is flooded, its carbon mineralization rate is inhibited, but its $\mathrm{CH}_{4}$ yield is increased. Thus, ground thawing changes the permafrost carbon balance, leading to ecological succession (Merritt et al., 2020). On the millennial scale, thermokarst lakes can change from atmospheric carbon sources into sinks (Cox et al., 2000; Elberling et al., 2013; Webb et al., 2016; Pries et al., 2016).

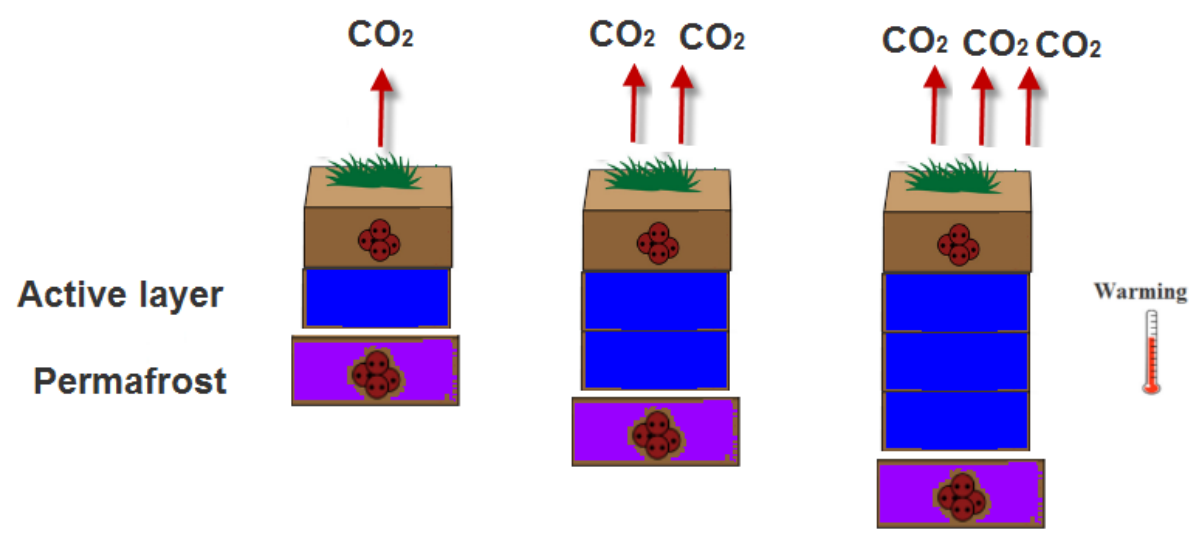

Figure 3. A schematic diagram of effects of permafrost on ecosystem respirations

As a warming climate continues to promote emissions of soil carbon, permafrost zones are likely to become huge carbon sources (Zak et al., 1999; Grosse et al., 2016). The huge carbon pools in high-latitude depermafrost ecosystems are susceptible to climate warming. This has always been a hotspot in research on climate change. The rapid warming of high-latitude and high-altitude regions is accelerating the decomposition of permafrost carbon and releasing large quantities of greenhouse gases into the atmosphere (Turetsky et al., 2020). Permafrost carbon is affected by ground thawing, and the resulting emissions load can be enormous. In fact, this has become focal point in climate negotiations (Merritt et al., 2020). Continuous monitoring showed that thermal melt slump resulted in enhanced respiration of exposed bare soil, and the ecosystem in the region changed from carbon sink to carbon source (Mu et al., 2017) (Fig. 4). At the same time, the transport of water, dissolved organic carbon and minerals due to thermal melt slump enhanced the methanogenic process and denitrification ability, which further accelerated and nitrous oxide emissions (Yang et al., 2018). Some of the soil carbon is converted into greenhouse gases and the other is released as surface runoff flows into rivers and lakes.

The increase of temperature has significantly degraded the frozen soil, mainly manifested in the deepening of the thickness of the active layer and the increasing frequency of freeze-thaw alternation. Freeze thaw alternation can promote the decomposition of organic debris and the mineralization of carbon and nitrogen, enhance the respiration of soil animals, plants and microorganisms, and increase the emission 
fluxes of $\mathrm{CO}_{2}, \mathrm{CH}_{4}$ and $\mathrm{N}_{2} \mathrm{O}$. The increase of temperature changes the physical and chemical characteristics of soil and enhances the activity of soil microorganisms, so as to enhance soil respiration and emit more $\mathrm{CO}_{2}$. However, the $\mathrm{CO}_{2}$ emission intensity caused by warming shows great differences due to different climatic conditions, surface vegetation, soil organisms and warming range (Yu et al., 2009; Li et al., 2011). Under the influence of temperature change, no matter whether the emission of $\mathrm{CO}_{2}, \mathrm{CH}_{4}$ and $\mathrm{N}_{2} \mathrm{O}$ in frozen soil increases or decreases, its mechanism is mainly that the soil temperature change caused by climate warming changes the activity of key microbial flora (mainly including methanogens, methane oxidizing bacteria, nitrifying bacteria and denitrifying bacteria) in the process of carbon and nitrogen transformation, and promotes or inhibits the decomposition of soil nutrients by microorganisms, Then affect the fluxes of $\mathrm{CO}_{2}$, $\mathrm{CH}_{4}$ and $\mathrm{N}_{2} \mathrm{O}$. In addition, temperature changes can regulate soil physical, chemical and biological properties, delay or shorten the growth period of soil plants, and indirectly affect the changes of $\mathrm{CO}_{2}, \mathrm{CH}_{4}$ and $\mathrm{N}_{2} \mathrm{O}$ fluxes (Wang et al., 2002; Geng et al., 2013).

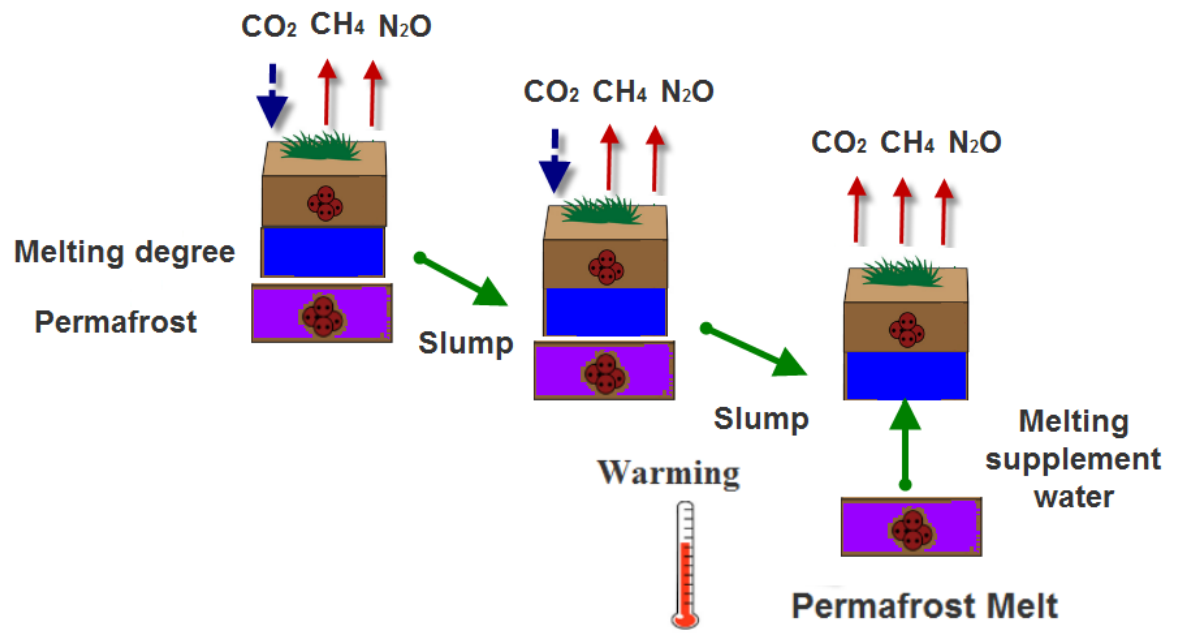

Figure 4. Impacts of permafrost degradation on soil moisture, dissolved organic carbon and the release of greenhouse gases $\left(\mathrm{CO}_{2}, \mathrm{CH}_{4}, \mathrm{~N}_{2} \mathrm{O}\right)$ and the arrows indicate the direction and potential of ecosystem greenhouse gas exchange during the growing seasons

Water conditions mainly affect the change of $\mathrm{CH}_{4}$ flux from two aspects: $\mathrm{CH}_{4}$ production and oxidation. In some studies, five gradients of $30 \%, 45 \%, 60 \%, 75 \%$ and $90 \%$ (field capacity) were set in to study the effects of different water conditions on $\mathrm{CH}_{4}$ emission from alpine meadow (Wang et al., 2016). It was found that the soil water content was between $30 \% \sim 60 \%$ of field capacity, and the alpine meadow showed a sink of methane. At this time, the absorption of $\mathrm{CH}_{4}$ was greater than the emission, but the absorption decreased gradually with the increase of water. This is because water filling the soil gap makes the gas difficult to diffuse and the $\mathrm{CH}_{4}$ absorption flux decreases. At the same time, the increase of water affects the activity of soil microorganisms, gradually changing it from a good gas process to a bad gas process, and $\mathrm{CH}_{4}$ oxidizing bacteria are limited (Wu et al., 2010; Wang et al., 2016). The soil water content is between 60\% $90 \%$ of the field water capacity, the $\mathrm{CH}_{4}$ emission rate increases, and its emission increases with the increase of water content. The alpine meadow is the source of $\mathrm{CH}_{4}$.

Soil is the main emission source of $\mathrm{N}_{2} \mathrm{O}$. Soil moisture directly affects nitrification and denitrification by affecting the content of $\mathrm{O}_{2}$ in soil, and indirectly affects the production 
and emission of $\mathrm{N}_{2} \mathrm{O}$. When the water content is lower than the critical value of water and the soil permeability is strong, $\mathrm{N}_{2} \mathrm{O}$ mainly comes from chemical action, and $\mathrm{N}_{2} \mathrm{O}$ emission increases with the increase of water content. When the soil has accumulated water for a long time, the denitrification process is the main source of $\mathrm{N}_{2} \mathrm{O}$ (Mikan and Schimel, 2002; Wu et al., 2010; Wang et al., 2016), but the $\mathrm{O}_{2}$ supply decreases and the $\mathrm{N}_{2}$ proportion increases, resulting in the reduction of $\mathrm{N}_{2} \mathrm{O}$ emission with the increase of water content. Therefore, too low or too high soil water content is not conducive to $\mathrm{N}_{2} \mathrm{O}$ emission. In forest ecosystem, the response of soil $\mathrm{N}_{2} \mathrm{O}$ emission range to water content varies with forest type, which may be due to the different organic matter and other nutrients contained in different types of litter, resulting in different substrates in biochemical process (Wu et al., 2010; Geng et al., 2013; Wang et al., 2016). During the growing season, the alpine meadow ecosystem has abundant precipitation, enhanced microbial activities and promoted $\mathrm{N}_{2} \mathrm{O}$ emission; The cold temperature in the nongrowing season leads to the reduction of microbial activity, and part of $\mathrm{N}_{2} \mathrm{O}$ is frozen in the soil and difficult to release to the outside world, inhibiting $\mathrm{N}_{2} \mathrm{O}$ emission (Wu et al., 2010; Wang et al., 2016).

There are large differences in the response sensitivity of different ecosystem components to climate change (Vishnivetskaya et al., 2006; Hassan et al., 2016). Climate change affects the carbon cycle of Arctic terrestrial ecosystems by changing temperatures, precipitation, snow cover and growth season length. In the future trend of increasing temperature and precipitation, the biomass of most Arctic vegetation will increase, so that more carbon will enter the Arctic terrestrial ecosystem. and higher temperature usually accelerates SOC microbial decomposition and greenhouse gas release. This feedback can accelerate climate change, but the scale of greenhouse gas emissions and their impact on climate change remain uncertain (Wang et al., 2002; Geng et al., 2013; Wang et al., 2016). Some research temperature and moisture are considered to be the main drivers of organic carbon mineralization (Bergero et al., 1999; Hassan et al., 2016). However, some studies have suggested that the sensitivity of SOC to temperature is not strong, and the effect of temperature increase is mainly the soil inert organic carbon component (Wang et al., 2002; Geng et al., 2013; Wang et al., 2016; Hassan et al., 2016). However, the intensity of the effect of temperature and water content on SOC mineralization rate is still poorly understood. in addition, the multi-year frozen soil carbon loss associated with wildfire, river and coastal erosion may not be well addressed in the global model.

\section{Microbial mechanisms of permafrost carbon conversion under a warming climate}

\section{Microbial activities under a warming climate}

Permafrost not only contains a huge amount of organic carbon matter, it is also inhabited by a rich variety of microbial communities. As survivors, microorganisms can engage in metabolism and reproduction under harsh living conditions, such as oligotrophic status, low temperature, freeze-thaw cycles, ultraviolet and polar radiation (Deng et al., 2015; Zhang et al., 2015). Permafrost is also inhabited by large quantities of microbial communities of various kinds, which can metabolize and reproduce under similarly harsh conditions (Xue et al., 2016; Salmon et al., 2016). In the biogeochemical cycling in permafrost regions, soil microbes play vital roles. As key bonds in ecosystems, they are highly sensitive to climate change; they are capable of linking underground soil nutrient systems with surface vegetation, and; thus, they are sensitive biological indicators for early warning of ecosystem changes in cold regions. A significant positive 
correlation was observed between the NPP and atmospheric $\mathrm{CO}_{2}$ concentration. The impact of permafrost degradation on NPP differed with regional environment. The NPP had a significant positive correlation with the mean annual ground temperature, but a negative correlation with the annual maximum permafrost depth (Mao et al., 2012; Hao et al., 2018; Feng et al., 2019).

Soil freezing and thawing occurs when the soil temperature changes around $0{ }^{\circ} \mathrm{C}$, and temperature is the dominant factor in the occurrence of freezing and thawing. Most studies show that there is a good correlation between forest soil respiration rate and soil surface temperature (Wu et al., 2010; Geng et al., 2013; Wang et al., 2016). Repeated freezing and thawing and a series of complex processes caused by it. The quantitative change of "living" microorganisms in frozen soil is consistent with the change characteristics of melting and freezing of frozen soil due to climate change. Many studies used pure culture method, selected two typical frozen soil soils of high latitude and high altitude frozen soil for bacterial isolation and culture, preliminarily obtained the community structure and diversity of culturable bacteria in the soil of high latitude and high altitude frozen soil areas in China, and compared the similarities and differences between them. The number of colonies isolated from soil in different frozen soil areas is different. The reason may be that the material basis necessary for the growth of soil microorganisms includes carbon source, nitrogen source, inorganic salt, growth factor and water (Mikan and Schimel, 2002; Puser et al., 2006), and the amount affects the number and species of soil microorganisms (Puser et al., 2006).

Seasonal freeze-thaw processes and soil physicochemical properties affect both the microbial quantities and species. Soil microbes are one of the most active components of soil system, and their biomass, activity, and community structures are strongly affected by changes in soil temperature, humidity, and micro-environment. Investigating the responses of soil microbes to a warming climate is crucial for predicting changes in the carbon stock of terrestrial ecosystems (Yao et al., 2006; Zhang et al., 2015; Das et al., 2017). Permafrost is featured by stable low temperature, low nutrient and continuous exposure to low level radiation. The metabolism of microorganisms in permafrost is at a relatively low level, with low frequency of gene mutation. Studying the characteristics of the microbial community structure in permafrost helps better understand the adaptive characteristics and genetic indicators of microorganisms in cold environment (Table 1).

Since the 1950s, researchers have studied mold in polar snow, mainly from Thyronectria antarctica var.hyperantarctica, Coleroa turfosorum, Bryosphaeria megaspora, Epibryon chorisodontii, Microdochium nivale, Sclerotinia borealis belonging to Ascomycetes. Trichoderma polysporum; Typhula ishikariensis, Microbotryum bistortarum, Polygonum viviparum; attributable to the Basidiomycetes Rhizopus, Bryum antarcticum; attributable to the Oomycetes comnium palustre, Calliergon stramineum and Tomenthypnum nitens. These fungi are mostly cold resistant species and have a variety of cold adaptation mechanisms (Tojo and Newsham, 2012). Up to now, fungal activities of fungi have been found in various elements of the cryosphere (Table 2). Hassan et al. (2016) conducted a comprehensive review of this research field.

In permafrost ecosystems, soil microbes promote the decomposition of organic matter and the conversion of soil nutrients, link underground soil nutrient systems with surface vegetation, and are highly sensitive to climate change (Yakushev et al., 2014; Zhou et al., 2017). So far, existing studies on permafrost microbes mainly concentrate on the following two aspects: 1) Effects of freeze-thaw action on soil microbes under a warming 
climate, and; 2) Correlations of the structures and diversity of permafrost microbial communities with various environmental factors. Facilitated by the rise of cultureindependent molecular biological methods, researchers have made extensive and profound inquiries for exploring microbial communities in frozen soils. The structures and diversity of permafrost microbial communities have been found to be influenced by many diverse factors. For example, Fierer et al. (2006) found that across a wide area, soil $\mathrm{pH}$ was the primary influencing factor for microbial communities. This was further confirmed by Chu et al. (2010) after the investigations of the soil bacterial community structures at 29 tundra sites in Alaska and other Arctic regions.

Table 1. Diversity and number of culturable microorganisms in permafrost

\begin{tabular}{|c|c|c|c|}
\hline Type & Microbe totality & Dominant microflora & Reference \\
\hline (Arctic) & & & \\
\hline Kolyma lowland & $10^{3} \sim 10^{8} \mathrm{cell} \cdot \mathrm{gdw}^{-1}$ & -- & Gillchinsky et al., 1989 \\
\hline $\begin{array}{l}\text { Spitsbergen, } \\
\text { Northern }\end{array}$ & $\begin{array}{c}1.7 \times 10^{9} \pm 2.4 \times 10^{8} \\
\text { cell } \cdot \mathrm{gdw}^{-1}\end{array}$ & Cellulomonas & Hansen et al., 2007 \\
\hline Norway & $\begin{array}{c}1.7 \times 10^{9} \pm 2.4 \times 10^{8} \\
\text { cell } \cdot \mathrm{gdw}^{-1}\end{array}$ & Arthrobacter & \\
\hline Eureka & $\begin{array}{l}10^{1} \sim 10^{4} \mathrm{cell} \cdot \mathrm{gdw}^{-1} \\
10^{1} \sim 10^{4} \mathrm{cell} \cdot \mathrm{gdw}^{-1} \\
10^{1} \sim 10^{4} \mathrm{cell} \cdot \mathrm{gdw}^{-1}\end{array}$ & $\begin{array}{c}\text { Acidobacteria, Gemmatimonadetes, } \\
\text { Bacteroidetes, Plantomycetes, } \\
\text { Firmicutess,Proteobacteria }\end{array}$ & Seven et al., 2007 \\
\hline (Antarctica) & & & \\
\hline Marble Point & $\begin{array}{c}7.8 \times 10^{7} \pm 1.3 \times 10^{8} \\
\text { cell } \cdot \mathrm{gdw}^{-1} \\
7.8 \times 10^{7} \pm 1.3 \times 10^{8} \\
\text { cell } \cdot \mathrm{gdw}^{-1}\end{array}$ & $\begin{array}{l}\text { Bacteroidetes, } \\
\text { Acidobacteria }\end{array}$ & Aislabie et al., 2006 \\
\hline $\begin{array}{l}\text { Bull pass } \\
\text { Vanda }\end{array}$ & $\begin{array}{c}10^{6} \sim 2.3 \times 10^{7} \mathrm{cell} \cdot \mathrm{gdw}^{-1} \\
3.6 \times 10^{7} \sim 1.2 \times 10^{8} \\
\text { cell } \cdot \mathrm{gdw}^{-1}\end{array}$ & $\begin{array}{l}\text { Bacteroidetes, } \\
\text { Bacteroidetes, }\end{array}$ & \\
\hline Mt.Fleming & $\begin{array}{l}<10^{6} \mathrm{cell} \cdot \mathrm{gdw}^{-1} \\
<10^{6} \mathrm{cell} \cdot \mathrm{gdw}^{-1}\end{array}$ & $\begin{array}{c}\text { Arthrobacter, } \\
\gamma \text {-proteobacteria }\end{array}$ & \\
\hline $\begin{array}{l}\text { South Shetland } \\
\text { Archipelago }\end{array}$ & $\begin{array}{ll}-- \\
--\end{array}$ & $\begin{array}{l}\text { Bacteroidetes, } \\
\text { Acidobacteria }\end{array}$ & \\
\hline & $\begin{array}{l}10^{3} \sim 10^{8} \mathrm{cell} \cdot \mathrm{gdw}^{-1} \\
10^{3} \sim 10^{8} \mathrm{cell} \cdot \mathrm{gdw}^{-1}\end{array}$ & $\begin{array}{c}\text { Actinobacteria, } \\
\text { Firmicutess }\end{array}$ & $\begin{array}{l}\text { Horowitz et al., } 1972 \\
\text { Cowan et al., } 2002\end{array}$ \\
\hline $\begin{array}{l}\text { (Tibetan } \\
\text { Palteau) }\end{array}$ & & & \\
\hline $\begin{array}{l}\text { Beilu River } \\
\text { Basin }\end{array}$ & ND & $\begin{array}{l}\text { Arthrobacter, } \\
\text { Pseudomonas }\end{array}$ & Zhang et al., 2007 \\
\hline $\begin{array}{l}\text { Beilu River } \\
\text { Basin } \\
\text { (Tianshan } \\
\text { Mountains) }\end{array}$ & $\begin{array}{c}1.0 \times 10^{7} \sim 3.8 \times 10^{9} \\
\text { cell } \cdot \mathrm{gdw}^{-1}\end{array}$ & -- & Fang et al., 2004 \\
\hline $\begin{array}{l}\text { Tianshan } \\
\text { Mountains }\end{array}$ & $2.5 \sim 6 \times 10^{5} \mathrm{CUF} \cdot \mathrm{gdw}^{-1}$ & Arthrobacter & Bai et al., 2006 \\
\hline
\end{tabular}

The continuous warming increases the thawing depth of the soil, resulting in a significant difference between the warming and the soil environment on the same ground, so the microbial community is unlikely to adapt to the warming. Because the temperature sensitivity of soil inert organic carbon is higher than that of unstable soil organic carbon, the higher microbial function of inert soil organic carbon decomposition under warming 
conditions will aggravate the soil carbon instability related to ecosystem respiration; while for deep soil, the warming effect of frozen soil area is often more significant, which contributes to ecosystem respiration. therefore, we predict that these microbial communities will continue to provide positive feedback for climate warming. Overall, the warming experiments significantly changed the bacterial composition and functional structure of the microbial community in the permafrost region and revealed its sensitivity to warming (Tables 1, 2). soil thawing depth is the most important factor affecting bacterial taxonomic composition, carbon decomposition potential and network topological properties, indicating that warming-induced thawing of permafrost regions basically reconstructs the associated bacterial communities. Therefore, we believe that the response of microorganisms to long-term warming will lead to positive feedback in the tundra region to promote carbon decomposition.

Table 2. Fungal genus/species distributed in permafrost

\begin{tabular}{|c|c|c|}
\hline Type & Fungal genus/species & Reference \\
\hline Franz Joseph Land & $\begin{array}{c}\text { Geomyces, Phialophora, Phoma, } \\
\text { Acremonium, Thelebolus, Mortierella. }\end{array}$ & Bergero et al., 1999 \\
\hline $\begin{array}{c}\text { Northern Fennoscandia } \\
\text { Arctic }\end{array}$ & $\begin{array}{c}\text { Anthracoiedea echinospora, Anthracoidea } \\
\text { heterospora. }\end{array}$ & Scholler et al., 2003 \\
\hline Western Beringia & $\begin{array}{c}\text { Acanthophysium, Mortierella, Bensingtonia, } \\
\text { Cryptococcus }\end{array}$ & Lydolph et al., 2005 \\
\hline Arctic & Sordaria Phanerochaete, Phialocephala. & Lydolph et al., 2005 \\
\hline Tyrolean Alps & $\begin{array}{c}\text { Cenococcum geophilum, Sebacina sp, Cortinarius } \\
\text { sp. }\end{array}$ & $\begin{array}{l}\text { Muhlmann and Peintner, } \\
2008\end{array}$ \\
\hline Cliff ledges & $\begin{array}{c}\text { Cenococcum geophilum, Thelephoraceae sp, } \\
\text { Cortinarius sp. }\end{array}$ & Ryberg et al., 2009 \\
\hline High Arctic & $\begin{array}{c}\text { Cryptococcus, Rhizosphaera, Mycopaoous, } \\
\text { Melampsora, Mrakia, Tetracladium, } \\
\text { Phaeosphaeria, Venturia, Leptosphaeria. } \\
\text { G. Pannorum, Thelebolus microspores. } \\
\text { Mortierella sp. }\end{array}$ & Zhang and Yao, 2015 \\
\hline Antarctic Peninsula & $\begin{array}{c}\text { Firmicutess. } \\
\text { Thielavia Antarctica, Apiosordaria antarctica. }\end{array}$ & Goncalves et al., 2012 \\
\hline $\begin{array}{l}\text { King George Island } \\
\text { Antarctica }\end{array}$ & $\begin{array}{l}\text { Mucor hiemalis, Mortierella alpina, Umbelopsis } \\
\text { isabellina, Penicillium chrysogenum. }\end{array}$ & Stchigel et al., 2003 \\
\hline Damma Glacier & $\begin{array}{c}\text { Lemonniera, Tetracladium nainitalense, } \\
\text { Thelebolus microspores. }\end{array}$ & Brunner et al., 2011 \\
\hline Himalayan Glacier & $\begin{array}{c}\text { Phoma sclerotioides, P. antarctica, P. olivacea, P. } \\
\text { lutea, Pseudogymnoascus, T. Psychrophilum, T. } \\
\text { ellipsoideum, T. globosum. }\end{array}$ & Hassan et al., 2016 \\
\hline Plateau Glacier & $\begin{array}{c}\text { Antrodia, Eupenicillium, Sporobolomyces, } \\
\text { Candida, Cryptococcus, Trametes, Periconia, } \\
\text { Thelebolus, Trichoderma, Pueraria, }\end{array}$ & Wang et al., 2015 \\
\hline $\begin{array}{l}\text { Kunlun Mountains } \\
\text { Glacier }\end{array}$ & $\begin{array}{c}\text { Pseudogymnoascus, Beauveria, Pseudeurotium, } \\
\text { Fontanospora, Cordyceps, }\end{array}$ & Hassan et al., 2016 \\
\hline
\end{tabular}




\section{Microbial mediation in permafrost carbon conversion under a warming climate}

As an important part of the ecosystem, soil microorganisms participate in the cycling process of soil carbon elements and the mineralization process of soil organic matter, which play an important role in the global carbon cycle and in the decomposition and transformation of organic substance, the transformation and supply of nutrients. Fig. 5 is a schematic diagram of the relationship between microorganisms and soil carbon cycle in permafrost areas. Studies have revealed the viability of microorganisms is frozen or greatly depressed/slowed in time, where the nutrients in unfrozen/liquid water films are used for growth and proliferation. For instance, Nataliet al. (2015) found that bacterial metabolism could still produce $\mathrm{CO}_{2}$ at $-39{ }^{\circ} \mathrm{C}$. Thawing of permafrost is closely correlated with the release of trace gases, and ground warming boosts the decomposition rate of organic matter, particularly that from ancient times (Coolen and Orsi, 2015), resulting in the enhanced production of $\mathrm{CH}_{4}$ and $\mathrm{CO}_{2}$ (Romanovsky et al., 2008). A study on Alaskan peatlands show that since thawing of permafrost beginning at $3 \mathrm{ka} \mathrm{B}$. P., they are losing carbon sources at an annual net rate of $26 \mathrm{~g} / \mathrm{m}^{2}$. Although the carbon released from the ancient permafrost increases the carbon offset by plant growth, permafrost has become a giant carbon source (instead of carbon sink) in the biosphere under a warming climate. The emission of large amounts of greenhouse gases in turn promotes climate warming, positively feeding back to the climate system (Schuur et al., 2015; Natali et al., 2015). Thus, permafrost microbes participate in carbon cycling through metabolizing carbonaceous organic matter (Hultman et al., 2015).

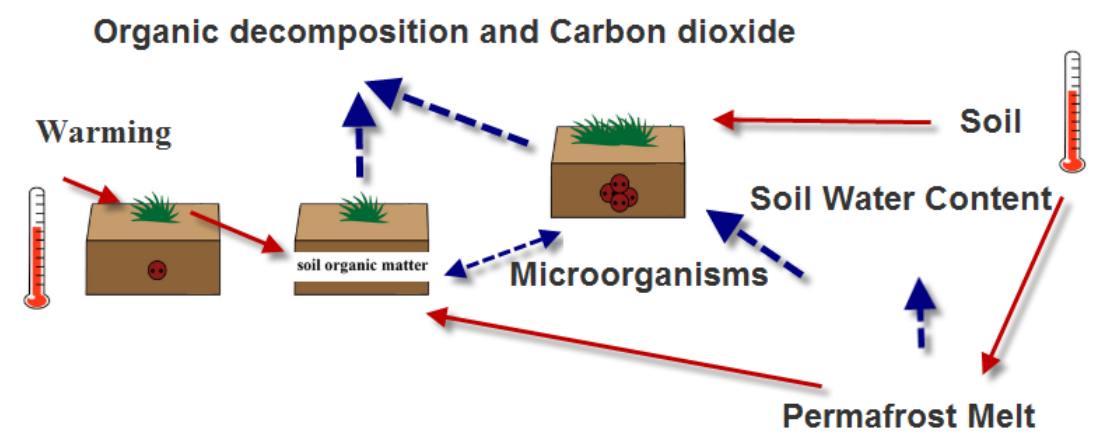

Figure 5. Mechanism of carbon and nitrogen exchange between microbial community and soil. Notes: A solid line with an arrow indicates positive feedback; The solid line of the flat arrow indicates negative feedback, and; Dashed arrows indicate positive or negative feedback

Based on previous studies, Zhou and Yang (2020) proposed the hypothesis that fiveyear warming yielded substantial changes in plant productivity, soil microclimate, and soil microbial community structures. Their results showed that, under a warming climate, the classification, composition, functional structures, and changes of soil microbial communities were both potential driving factors and ecological results. It was also discovered that climate warming greatly modified the composition and functional structures of permafrost bacterial communities. The thawing depth was the most significant influencing factor for bacterial classification and composition, carbon decomposition potential, and network topological properties. Permafrost was induced by climate warming fundamentally reconstructed those related bacterial communities. Thus, responses of microbes to long-term climate warming would create positive feed backs and promote carbon decomposition in permafrost zones. 


\section{Conclusion and prospect}

Permafrost carbon conversion has currently become a research hot spot. Summarizing latest research on the responses of permafrost carbon conversion to climate warming and the related microbial mechanisms, there are still several key problems await further investigations:

(1) Succession of vegetation communities in forest ecosystems: The degradation of permafrost induced by climate change gives rise to a series of environmental changes, such as increased activity layer thickness and hydrothermal instability, and alters forest ecosystems. For instance, the timberline of the main original constructive species of the Da Xing'anling Mountains in Northeast China (such as Larixgmelinii and Pinus sylvestris) has been elevated, and coniferous forests have experienced a succession towards deciduous mixed broad-leaved and coniferous forests. On account of in-situ monitoring conditions in the field, existing studies on climate change mostly resort to numerical simulations, which is fundamentally different from field in-situ experiments. Thus, it is still necessary to strengthen the continuous, long-term observation of permafrost experiment zones, especially in combination with changes in the biogeochemical cycling of soil carbon under a warming climate. In addition, existing studies have touched upon the effects of changing seasonal freeze-thaw processes on SOC, especially soil carbon fractions and soil carbon conversion characteristics.

(2) Shrinking permafrost wetlands: There is a symbiotic relationship between permafrost and wetlands, and the degradation of permafrost is accompanied by a rapid loss of soil water. As a consequence, the original wetlands on permafrost gradually shrink in areal extent due to the lack of water replenishment, and wetland ecosystems gradually change to meadow and farmland ecosystems. However, the interactions between wetlands and permafrost and the mechanisms by which they emit high levels of greenhouse gases still remain poorly known, and the monitoring of the effective substrates of soil activity is not adequately diversified. For this reason, efforts should be made to explore the microbial community structures and effective substrates of permafrost peatlands, and to analyze the structural characteristics and functional genes of the microbial communities playing dominant roles in the decomposition of soil organic matter, methanogensis, and other processes under a warming climate.

Due to the rapid expansion of human activities and industrialization process, greenhouse effect changes forest ecosystems at different scales. Over the next 40 50 years, if air temperature rises by $1.5^{\circ} \mathrm{C}$, the southern/lower limit of permafrost will continue to move northwards/upwards. With the degradation of permafrost, continuous permafrost may degrade first into discontinuous permafrost, and then into seasonal frost, resulting in the decomposition of carbon sources fixed by microbes. This degradation process is also accompanied by the production of $\mathrm{CO}_{2}$ through aerobic soil respiration or the emission of $\mathrm{CH}_{4}$ under anaerobic microbial action. Jointly, these processes intensify the greenhouse effect, producing positive feed backs to climate warming. To provide a base line for accurately predicting the intensity of greenhouse gas sources and sinks in permafrost regions and more effectively protect forest ecosystems under a changing climate, it is necessary to explore the effects of global warming on the conversion of permafrost carbon. and discuss the mediating mechanism of microbes in the responses of the conversion of permafrost carbon to global warming.

Climate warming has led to significant degradation of permafrost as manifested by increased active layer thickness and altered seasonal freeze-thaw processes. More frequent seasonal freeze-thaw cycles promote the decomposition of fragmental organic 
matter and the mineralization of organic carbon and nitrogen, and strengthen the respiration of soil animals, plants, and microbes, and increase $\mathrm{CO}_{2}, \mathrm{~N}_{2} \mathrm{O}$ and $\mathrm{CH}_{4}$ effluxes. Ground warming also modifies soil physiochemical properties and enhances soil microbial activity, resulting in enhanced soil respiration and $\mathrm{CO}_{2}$ emissions.

Frozen soil is a very important environmental factor on the earth's land surface. It is widely distributed and has unique hydrothermal characteristics. It is an extremely valuable natural resource. Bacteria account for a large proportion of many soil microorganisms, and make a great contribution to soil material circulation and energy flow. In the study of soil bacteria, there are many reports on agricultural areas, but there are few reports on soil bacteria in permafrost areas, especially in permafrost areas at high latitudes in China. As one of the extreme environments in the cryosphere, frozen soil covers a large area and is widely distributed. It is sensitive to global climate change. Compared with the traditional terrestrial and aquatic ecosystems of forests, farmland, oceans, lakes, rivers and atmosphere, there are few studies on soil microbial communities in the frozen soil extreme environment that is sparsely populated and not polluted by modern industry. Permafrost distribution area is a sensitive area of global climate change. The degradation of permafrost leads to the shrinkage of permafrost area, the decline of soil biodiversity function and the damage of ecological function, which is one of the important ecological problems we will study in the future.

Funding. This study was financially supported by China-Norway International Collaboration Project (Grant No.CHN-17/0019) and the project of Heilongjiang Province Key Laboratory of Cold Region Wetland Ecology and Environment Research of the Harbin University (No. 201910). The project of Young Doctoral Research of the Harbin University (No. 2020106).

\section{REFERENCES}

[1] Aislabie, J. M., Chhour, K. L., Saul, D. J., Miyauchi, S., Ayton, J., Paetzold, R. F., Balks, M. R. (2006): Dominant bacteria in soils of marble point and wright valley, Victoria land, Antarctica. - Soil Biology Biochemistry 38(10): 3041-3056.

[2] Anisimov, O. A., Nelson, F. E. (1996): Permafrost distribution in the northern hemisphere under scenarios of climatic change. - Global and Planetary Change 14: 59-72.

[3] Bai, Y., Yang, D., Wang, J., Xu, S., Wang, X., An, L. (2006): Phylogenetic diversity of culturable bacteria from alpine permafrost in the Tianshan Mountains, northwestern China. - Res Microbiol. 157: 741-751.

[4] Bergero, R., Girlanda, M., Varese, G. C., Intili, D., Luppi, A. M. (1999): Psychrooligotrophic fungi from arctic soils of Franz Joseph Land. - Polar Biology 21: 361368.

[5] Bracho, R., Natali, S., Pegoraro, E., Crummer, K. G., Christina, S., Celis, G., Hale, L., Wu, L., Yin, H., Tiedje, J. M. (2016): Temperature sensitivity of organic matter decomposition of permafrost region soils during laboratory incubations. - Soil Biology and Biochemistry 97: 1-14.

[6] Brown, J., Ferrians, O. J. Jr., Heginbottom, J. A., Melnikov, E. S. (2002): Circum-arctic map of permafrost and ground-ice conditions. - Version 2. Natl. Snow Ice Data Center/World Data Cent. Glaciol., Boulder, Co.

[7] Brunner, I., Plotze, M., Rieder, S., Zumsteg, A., Furrer, G., Frey, B. (2011): Pioneering fungi from the Damma glacier forefield in the Swiss Alps can promote granite weathering. - Geobiology 9: 266-279.

[8] Camill, P. (1999): Patterns of boreal permafrost peatland vegetation across environmental gradients sensitive to climate warming. - Canadian Journal of Botany 77(5): 721-733. 
[9] Camill, P., Clark, J. S. (2000): Long-term perspectives on lagged ecosystem responses to climate change: permafrost in boreal peat lands and the grassland/woodland boundary. Ecosystems 3(6): 534-544.

[10] Chu, F. (2010): Soil bacterial diversity in the arctic is not fundamentally different from that found in other biomes. - Environmental Microbiology 12(11): 2998-3006.

[11] Coolen, M. J., Orsi, W. D. (2015): The transcriptional response of microbial communities in thawing Alaskan permafrost soils. - Frontiers in Microbiology 6(6): 197.

[12] Cowan, D. A., Russell, N., Mamais, A., Sheppard, D. M. (2002): Antarctic Dry Valley mineral soils contain unexpectedly high levels of microbial biomass. - Extremophiles 6: 431-436.

[13] Cox, P. M., Betts, R. A., Jones, C. D., Spall, S. A., Totterdell, I. J. (2000): Acceleration of global warming due to carbon-cycle feedbacks in a coupled climate model. - Nature 408(6809): 184-187.

[14] Das, S., Ganguly, D., Mukherjee, A., Chakraborty, S., De, T. K. (2017): Soil urease activity of Sundarban Mangrove Ecosystem, India. - Advances in Microbiology 7(8): 617-632.

[15] Deane-Coe, K. K., Mauritz, M., Celis, G., Salmon, V., Schuur, E. A. G. (2015): Experimental warming alters productivity and isotopic signatures of tundra mosses. Ecosystems 18(6): 1070-1082.

[16] Deng, J., Gu, Y., Zhang, J., Kai, X., Zhou, J. (2015): Shifts of tundra bacterial and archaeal communities along a permafrost thaw gradient in Alaska. - Molecular Ecology 24(1): 222234.

[17] Dobbie, K. E., Smith, K. A. (2003): Nitrous oxide emission factors for agricultural soils in Great Britain: The impact of soil water - filled pore space and other controlling variables. - Global Change Biology 9(2): 204-218.

[18] Elberling, B., Michelsen, A., Schädel, C., Schuur, E. A. G., Christiansen, H., Berg, L., Tamstorf, M. P., Sigsgaard, C. (2013): Long-term $\mathrm{CO}_{2}$ production following permafrost thaw. - Nature Climate Change 3(10): 890.

[19] Feng, H., Ma, X., Zhang, G., Bai, Y., Fei, G. Q., Cheng, G. D., An, L. Z., Liu, G. X. (2004): Culturing and counting the microbial cells in permafrost on the Tibetan Plateau. - Journal of Glaciology and Geocryology 26(2): 182-187.

[20] Feng, R. F., Yang, W. Q., Zhang, J., Deng, R. J., Jian, Y., Lin, J. (2007): Effects of simulated elevated atmospheric $\mathrm{CO}_{2}$ concentration and temperature on soil enzyme activity in the subalpine fir forest. - Acta Ecologica Sinica 27(10): 4019-4026.

[21] Feng, J., Penton, C. R., He, Z., Nostrand, J. D. V., Yuan, M. M., Wu, L. Y., Wang, C., Qin, Y. J., Shi, Z. J., Guo, X. (2019): Long-Term warming in Alaska Enlarges the diazotrophic community in deep soils. - mBio 10(1): e02521-18.

[22] Feng, J. J., Wang, C., Lei, J. S. (2020): Warming-induced permafrost thaw exacerbates tundra soil carbon decomposition mediated by microbial community. - Microbiome 8: 3 . https://doi.org/10.1186/s40168-019-0778-3.

[23] Fierer, J. (2006): The diversity and biogeography of soil bacterial communities. Proceedings of the National Academy of Science of the United States of America 103(3): 626.

[24] Friedlingstein, P., Cox, P., Betts, R., Bopp, L., Bloh, W. V., Brovkin, V., Cadule, P., Doney, S., Eby, M., Fung, I. (2006): Climate-carbon cycle feedback analysis: Results from the $\mathrm{C}^{4}$ MIP model inter comparison. - Journal of Climate 19(14): 3337-3353.

[25] Ganzert, L., Lipsk, A., Hubberten, H. W., Dirk, W. (2011): The impact of different soil parameters on the community structure of dominant bacteria from nine different soil located on Livingston island, South Shetland Archipelago, Antarcica. - Microbiology Ecology 76(3): 476-491.

[26] Geng, S. C., Chen, Z. J., Zhang, J. H., Lou, X., Wang, X. X., Dai, G. H., Han, S. J., Yu, D. D. (2013): Soil methane fluxes of three forest types in Changbai Mountain of northeast China. - Chinese Journal of Ecology 32(5): 1091-1096. 
[27] Gilichinsky, D. A., Khlebnikova, G. M., Zvyagintsev, D. G., Fedorov-Davydov, D. G., Kudryavtseva, N. N. (1989): Microbiology of sedimentary materials in the permafrost zone. - International Geology Review 31(8): 847-858.

[28] Goncalves, V. N., Vaz, A. B. M., Rosa, C. A., Rosa, L. H. (2012): Diversity and distribution of fungal communities in lakes of Antarctica. - FEMS Microbiology Ecology 82: 459-471.

[29] Grogan, P., Chapin III, F. S. (2000): Initial effects of experimental warming on above-and belowground components of net ecosystemCO $\mathrm{CO}_{2}$ exchange in Arctic tundra. - Oecologia 1250: 512-520.

[30] Grosse, G., Goetz, S., McGuire, A. D., Romanovsky, V. E., Schuur, E. A. G. (2016): Changing permafrost in a warming world and feedbacks to the Earth system. Environmental Research Letters 11(4): 040201.

[31] Guo, X., Feng, J., Shi, Z., Zhou, X., Yuan, M., Tao, X., Lauren, H., Yuan, T., Wang, J., Qin, Y. (2018): Climate warming leads to divergent succession of grassland microbial communities. - Nature Climate Change 8(9): 813-818.

[32] Haeberli, W., Hohmann, R. (2008): Climate, glaciers and permafrost in the Swiss Alps 2050: Scenarios, consequences and recommendations. - In: Kane, D. L., Hinkel, K. M. (eds.) Proceedings, Ninth International Conference on Permafrost. Institute of Northern Engineering, University of Alaska Fairbanks: Alaska, USA, pp. 607-612.

[33] Hansen, A. A., Herbert, R. A., Mikkelsen, K., Jensen, L. L., Kristoffersen, T., Tiedje, J. M., Lomstein, B. A., Kai, W. F. (2007): Viability, diversity and composition of the bacterial community in a high Arctic permafrost soil from Spitsbergen, Northern Norway. Environmental Microbiology 9(11): 2870-2884.

[34] Hao, Z., Li, L., Fu, Y., Liu, H. (2018): The influence of bioregenerative life-support systemdietary structure and lifestyle on the gut microbiota: a 105-day ground based space simulation in Lunar Palace 1. - Environmental microbiology 20(10): 3643-3656.

[35] Hassan, N., Rafiq, M., Hayat, M., Shah, A. A., Hasan, F. (2016): Psychrophilic and psychrotrophic fungi: a comprehensive review. - Reviews in Environmental Science and Biotechnology 15: 147-172.

[36] Hayes, D. J., Kicklighter, D. W., Mcguire, A. D., Chen, M., Zhuang, Q., Yuan, F., Melillo, J. M., Wullschleger, S. D. (2014): The impacts of recent permafrost thaw on landatmosphere greenhouse gas exchange. - Environmental Research Letters 9: 45005.

[37] Horowitz, N. H., Cameron, R. E., Hubbard, J. S. (1972): Microbiology of the dry valleys of Antarctica. - Science 176: 242-245.

[38] Hultman, J., Waldrop, M. P., Mackelprang, R., David, M. M., McFarland, J., Blazewicz, S. J., Harden, J., Turetsky, M. R., Mcguire, A. D., Shah, M. B. (2015): Multi-omics of permafrost, active layer and thermokarst bog soil microbiomes. - Nature 521(7551): 208.

[39] Huntington, T. G. (2006): Evidence for intensification of the global water cycle: Review and synthesis. - Journal of Hydrology 319(1): 83-95.

[40] IPCC (2013): Climate Change 2013: The Physical Science Basis. - Contribution of Working Group I to Fifth Assessment Report of the Intergovernmental Panel on Climate Change.

[41] Jin, H. J., Li, S. X., Cheng, G. D., Wang, S. L., Xin, L. (2000): Permafrost and climatic change in China. - Global and Planetary Change 26(4): 387-404.

[42] Jin, H. J., Yu, Q. H., Guo, D. X., Li, Y. (2007): Degradation of permafrost in the Xing'anling Mountains, Northeastern China. - Permafrost and Periglac Process 18: 245258.

[43] Johnson, L. C., Shaver, U. R., Cades, D. H., Rastetter, E., Nadelhoffer, K., Giblin, A., Stanley, L. A. (2000): Plant carbon-nutrient interactions control $\mathrm{CO}_{2}$ exchange in Alaskan wet sedge tundra ecosystems. - Ecology 81(2): 453-469.

[44] Lawrence, D. M., Koven, C. D., Swenson, S. C., Riley, W. J., Slater, A. G. (2015): Permafrost thaw and resulting soil moisture changes regulate projected high-latitude $\mathrm{CO}_{2}$ and $\mathrm{CH}_{4}$ emissions. - Environmental Research Letters 10(9): 094011. 
[45] Li, L., Lei, G. C., Gao, J. Q., Lv, S., Zhou, Y., Jia, Y. F., Yang, M., Duoerji, S. (2011): Effect of water table and soil water content on methane emission flux at Carex muliensis marshes in Zoigê Plat-Eau. - Wetland Science 9(2): 173-178.

[46] Luo, Y. (2007): Terrestrial carbon-cycle feedback to climate warming. - Annual Review of Ecology, Evolution and Systematics 38(1): 683-712.

[47] Lydolph, M. C., Jacobsen, J., Arctander, P., Gilbert, M. T. P., Gilichinsky, D. A., Hansen, A. J., Willerslev, E., Lange, L. (2005): Beringian paleocology inferred from permafrostpreserved fungal DNA. - Applied and Environmental Microbiology 71: 1012-1017.

[48] Mao, D. H., Wang, Z. M., Luo, L., Han, J. X. (2012): Dynamic changes of vegetation net primary productivity in permafrost zone of Northeast China in 1982-2009 in response to global change. - Chinese Journal of Applied Ecology 23(6): 1511-1519.

[49] Melillo, J. M., Steudler, P. A., Aber, J. D., Newkirk, K., Morrisseau, S. (2002): Soil warming and carbon-cycle feedbacks to the climate system. - Science 298(5601): 21732176.

[50] Mikan, C. J., Schimel, J. P., Doyle A P. (2002): Temperature controls of microbial respiration in arctic tundra soils above and below freezing. - Soil Biology and Biochemistry 34(11): 1785-1795.

[51] Mu, C. C., Abbott, B. W., Zhao, Q., Wang, S. F., Wu, Q. B., Zhang, T. J. (2017): Permafrost collapse shifts alpine tundra to a carbon source but reduces $\mathrm{N}_{2} \mathrm{O}$ and $\mathrm{CH}_{4}$ release on the northern Qinghai-Tibetan Plateau. - Geophysical Research Letters 44(17): 8945-8952.

[52] Muhlmann, O., Peintner, U. (2008): Mycobionts of Salix herbacea on a glacier forefront in the Austrian Alps. - Mycorrhizae 18: 171-180.

[53] Nakatsubo, T., Bekku, Y. S., Uchida, M., Muraoka, H., Kume, A., Ohtsuka, T., Masuzawa, T., Kanda, H., Koizumi, H. (2005): Ecosystem development and carbon cycle on a glacier foreland in the high Arctic, Ny-Alesund, Sralbard. - J Plant Res 118(3): 173-179.

[54] Natali, S. M., Schuur, E. A. G., Rubin, R. L. (2012): Increased plant productivity in Alaskantundra as a result of experimental warming of soil and permafrost. - Journal of Ecology 100(2): 488-498.

[55] Natali, S. M., Schuur, E. A. G., Mauritz, M., Schade, J. D., Celis, G., Crummer, K. G., Johnston, C., Krapek, J., Pegoraro, E., Salmon, V. G. (2015): Permafrost thaw and soil moisture driving $\mathrm{CO}_{2}$ and $\mathrm{CH}_{4}$ release from upland tundra. - Journal of Geophysical Research Biogeosciences 120(3): 525-537.

[56] Nemani, R. R. (2003): Climate driven increases in global terrestrial net primary production from 1982 to 1999 . - Science 300(5625): 1560-1563.

[57] Parkinson, S. V. D. (2009): Soil biological criteria as indicators of soil quality: Soil microorganisms. - American Journal of Alternative Agriculture 7(1): 33-37.

[58] Ping, C. L., Jastrow, J. D., Jorgenson, M. T., Michaelson, G. J., Shur, Y. L. (2015): Permafrost soils and carbon cycling. - Soil Discussions 1(1): 147-171.

[59] Post, W. M., Emanuel, W. R., Zinke, P. J., Stangenberger, A. G. (1982): Soil carbon pools and world life zones. - Nature 298(5870): 156-159.

[60] Pries, C. E. H., Schuur, E. A., Natali, S. M., Crummer, K. (2016): Old soil carbon losses increase with ecosystem respiration in experimentally thawed tundra. - Nature Climate Change 6(2): 214.

[61] Puser, R., Flessah, H., Russow, R., Schmidt, G., Buegger, F., Munch, J. C. (2006): Emission of $\mathrm{N}_{2} \mathrm{O}, \mathrm{N}_{2}$ and $\mathrm{CO}_{2}$ from soil fertilized with nitrate: Effect of compaction, soil moisture and rewetting. - Soil Biology and Biochemistry 38(2): 263-274.

[62] Qin, Y., Yi, S. H., Li, N. J. (2012): Advance in studies of carbon cycling on alpine grasslands of the Qinghai-Tibetan Plateau. - Acta Prata culturae Sinica 21(6): 275-285.

[63] Rustad, L., Campbell, J., Marion, G., Norby, R., Mitchell, M., Hartley, A., Cornelissen, J., Gurevitch, J. (2001): A meta-analysis of the response of soil respiration, net nitrogen mineralization, and aboveground plant growth to experimental ecosystem warming. Oecologia 126(4): 513-562. 
[64] Ryberg, M., Larsson, E., Molau, U. (2009): Ectomycorrhizal diversity on Dryas octopetala and Salix reticulata in an alpine cliff ecosystem. Arctic. - Antarctic and Alpine Research 41: 506-514.

[65] Salmon, V. G., Soucy, P., Mauritz, M., Celis, G., Natali, S. M., Mack, M. C., Schuur, E. A. G. (2016): Nitrogen availability increases in a tundra ecosystem during five years of experimental permafrost thaw. - Global Change Biology 22(5): 1927-1941.

[66] Schaefer, K., Lantuit, H., Romanovsky, V. E., Schuur, E. A. G., Witt, R. (2014): The impact of the permafrost carbon feedback on global climate. - Environmental Research Letters 9(8): 085003.

[67] Schmitt, A., Glaser, B., Borken, W., Schuur, E. A. G., Witt, R. (2008): Repeated freezethaw cycles changed organic matter quality in a temperate forest soil. - Journal of Plant Nutrition and Soil Science 171: 707-718.

[68] Scholler, M., Schnittler, M., Piepenbring, M. (2003): Species of Anthracoidea (Ustilaginales, Basidiomycota) on Cyperaceae in Arctic Europe. - Nova Hedwigia 76: 415428.

[69] Schuur, E. A. G., Mcguire, A. D., Schädel, C., Grosse, G., Harden, J. W., Hayes, D. J., Hugelius, G., Koven, C. D., Kuhry, P., Lawrence, D. M., Natali, S. M., Olefeldt, D., Romanovsky, V. E., Schaefer, K., Turetsky, M. R., Treat, C. C., Vonk, J. E. (2015): Climate change and the permafrost carbon feedback. - Nature 520(7546): 171.

[70] Shannon, M. H., Bhavaraju, L., Jorge, L. M. R., Corien, B., Gilichinsky, D. A., Tiedje, J. M. (2010): Characterization of abacterial community from a Northeast Siberianseacoast permafrost sample. - Microbiology Ecology 74(1): 103-113.

[71] Singh, B. K., Bardgett, R. D., Smith, P., Reay, D. S. (2010): Microorganisms and climate change: terrestrial feedbacks and mitigation options. - Nature Reviews Microbiology 8(11): 779-790.

[72] Smith, K. A., Thomson, P. E., Clayton, H., McTaggart, I. P., Conen, F. (1998): Effects of temperature, water content and nitrogen fertilization on emissions of nitrous oxide by soils. - Atmospheric Environment 32(19): 3301-3309.

[73] Song, C. C., Wang, X. W., Miao, Y. Q. (2013): Effects of permafrost thaw on carbon emissions under aerobic and anaerobic environments in the Great Hing'an Mountains China. - Science of the Total Environment 487(1). http://dx.doi.org/10.1016/j.scitotenv.09.083.

[74] Song, C. C., Wang, Y. Y., Wang, Y. S., Zhao, Z. C. (2014): Dynamics of $\mathrm{CO}_{2}, \mathrm{CH}_{4}$ and $\mathrm{N}_{2} \mathrm{O}$ emission fluxes from mires during freezing and thawing season. - Environmental Science 26(4): 7-12.

[75] Stchigel, A. M., Guarro, J., Cormack, W. M. (2003): Apiosordaria antarctica and Thielavia antarctica, two new ascomycetes from ntarctica. - Mycologia 95: 1218-1226.

[76] Steven, B., Briggs, G., McKay, C. P., Pollard, W. H., Greer, C. W., Whyte, L. G. (2007): Characterization of the microbial diversity in a permafrost sample from the Canadian high Arctic using culture-dependent and culture-independent methods. - FEMS Microbiology Ecology 59: 513-523.

[77] Turetsky, M. R., Abbott, B. W., Jones, M. C., Anthony, K. W., Olefeldt, D., Schuur, E. A. G., Grosse, G., Kuhry, P., Hugelius, G., Koven, C. (2020): Carbon release through abrupt permafrost thaw. - Nature Geoscience 13: 138-143.

[78] Vishnivetskaya, T. A., Petrova, M. A., Urbance, J., Ponder, M., Moyer, C. L., Gilichinsky, D. A., Tiedje, J. M. (2006): Bacterial community in ancient Siberian permafrost as characterized by culture and culture-independent methods. - Astrobiology 6(3): 400-414.

[79] Vorobyova, E., Soina, V., Gorlenko, M., Minkovskaya, N., Zalinova, N., Mamukelashvili, A., Gilichinsky, D., Rivkina, E., Vishnivetskaya, T. (1997): The deep cold biosphere: facts and hypothesis. - FEMS Microbiol Reviews 20(3-4): 277-290.

[80] Walther, G. R., Post, E., Convey, P., Menzel, A., Parmesan, C., Beebee, T. J. C., Fromentin, J., Hoegh-Guldberg, O., Bairlein, F. (2002): Ecological responses to recent climate change. - Nature 416(6879): 389-395. 
[81] Wan, S., Luo, Y., Wallace, I. L. (2002): Changes in microclimate induced by experimental warming and clipping in tallgrass prairie. - Global Change Biology 8(8): 754-768.

[82] Wang, C. R., Huang, G. H., Liang, Z. B., Wu, J., Xu, G. Q., Yue, J., Shi, J. (2002): Advances in the research on sources and sinks of $\mathrm{CH}_{4}$ and $\mathrm{CH}_{4}$ oxidation (uptake) in soil. - Chinese Journal of Applied Ecology 13(12): 1707-1712.

[83] Wang, M., Jiang, X., Wu, W., Hao, Y., Su, Y., Cai, L., Xiang, M., Liu, X. (2015): Psychrophilic fungi from the world's roof. - Persoonia 34: 100-112.

[84] Wang, D. X., Gao, Y. H., An, X. J., Wang, R., Xie, Q. Y. (2016): Responses of greenhouse gas emissions to water table fluctuations in an alpine wetland on the Qinghai-Tibetan Plateau. - Acta Prataculturae Sinica 25(8): 27-35.

[85] Webb, E. E., Schuur, E. A. G., Natali, S. M., Oken, K. L., Bracho, R., Krapek, J. P., Risk, D., Nickerson, N. R. (2016): Increased wintertime $\mathrm{CO}_{2}$ loss as a result of sustained tundra warming. - Journal of Geophysical Research: Biogeosciences 121(2): 249-265.

[86] Welker, J. M., Fahnestock, J. T., Henry, G. H. R., O'Dea, K. W., Chimner, R. A. (2004): $\mathrm{CO}_{2}$ exchange in three Canadian High Arctic ecosystems; response to long-term experimental warming. - Global Change Biology 10(12): 1981-1995.

[87] Wu, X., Brggemann, N., Gasche, R., Shen, Z. Y., Wolf, B., Butterbach-Bahl, K. (2010): Environmental controls over soil atmosphere exchange of $\mathrm{N}_{2} \mathrm{O}, \mathrm{NO}$ and $\mathrm{CO}_{2}$ in a temperate Norway spruce forest. - Global Biogeochemical Cycles 24(2): 1-16.

[88] Xu, X. F., Tian, H. Q., Wan, S. Q. (2007): Climate warming impacts on carbon cycling in terrestrial ecosystems. - Journal of Plant Ecology 31(2): 175-188.

[89] Xue, K., Yuan, M. M., Shi, Z. J., Qin, Y., Deng, Y., Cheng, L., Wu, L., He, Z., Nostrand, V., Nostrand, J. D. V., Bracho, R., Natali, S., Schuur, E. A. G., Luo, C., Konstantinidis, K. T., Wang, Q., Cole's, J. R., Tiedje, J. M., Luo, J. Q., Zhou, J. Z. (2016): Tundra soil carbon is vulnerable to rapid microbial decomposition under climate warming. - Nature Climate Change 6(6): 595.

[90] Yakushev, A. V., Kuznetsova, I. N., Blagodatskaya, E. V., Blagodatsky, S. A. (2014): Temperature dependence of the activity of polyphenol peroxidases and polyphenol oxidases in modern and buried soils. - Eurasian Soil Science 47(5): 459-465.

[91] Yang, G., Peng, Y., Olefeldt, D., Chen, Y., Wang, G., Li, F., Zhang, D., Wang, J., Liu, L., Qin, S., Sun, T., Yang, Y. (2018): Changes in methane flux along a permafrost thaw sequence on the Tibetan Plateau. - Environmental Science \& Technology 52(3): 12441252.

[92] Yao, X. H., Min, H., Lu, Z. H., Yuan, H. P. (2006): Influence of acetamiprid on soil enzymatic activities and respiration. - European Journal of Soil Biology 42: 120-126.

[93] Yu, J. B., Liu, J. S., Sun, Z. G., Wang, J., Yang, J., Meixner, F. X. (2009): $\mathrm{N}_{2} \mathrm{O}$ and $\mathrm{CH}_{4}$ fluxes and influencing factors in fresh marshes in northeastern China. - Science in China Press (Ser. D Earth Sciences) 39(2): 177-187.

[94] Zak, D. R., Holmes, W. E., Macdonald, N. W., Pregitzer, K. S. (1999): Soil Temperature, Matric Potential, and the Kinetics of Microbial Respiration and Nitrogen Mineralization. Soil Science Society of America Journal 63(3): 575-584.

[95] Zhang, G., Ma, X., Niu, F., Dong, M., Feng, H., An, L., Cheng, G. (2007): Diversity and distribution of alkaliphilic psychrotolerant bacteria in the Qinhai-Tibet Plateau permafrost region. - Exteremophiles 11: 415-424.

[96] Zhang, T., Yao, Y. F. (2015): Endophytic fungal communities associated with vascular plants in the high Arctic zone are highly diverse and hostplant specific. - PLOS One 10(6): e0130051.

[97] Zhang, Y., Ling, J., Yang, Q., Wen, C., Yan, Q., Sun, H., Nostrand, J. D. V., Shi, Z., Zhou, J., Dong, J. (2015): The functional gene composition and metabolic potential of coralassociated microbial communities. - Scientific reports 5: 16191.

[98] Zhou, X., Wang, S. J., Chen, C. (2017): Modeling the effects of tree species and temperature on soil's extracellular enzyme activity in 78-year-old tree plantations. Biogeosciences 14: 5393-5402. 
[99] Zhou, J. Z., Yang, Y. F. (2020): Warming-induced permafrost thaw exacerbates tundrasoil carbon decomposition mediated by microbial community. - Microbiome. On line.

[100] Zhu, J. T., Chen, N., Zhang, Y. J., Liu, Y. J. (2016): Effects of experimental warming on net ecosystem $\mathrm{CO}_{2}$ exchange in northern Xizang alpine meadow. - Chinese Journal of Plant Ecology 40(12): 1219-1229. 